\title{
Compatibility of Atheta coriaria with other biological control agents and reduced-risk insecticides used in greenhouse floriculture integrated pest management programs for fungus gnats
}

\author{
S. Jandricic, C.D. Scott-Dupree ${ }^{1}$ \\ Department of Environmental Biology, University of Guelph, Guelph, Ontario, \\ Canada N1G 2W1

\section{A.B. Broadbent} \\ Southern Crop Protection and Food Research Centre, Agriculture and Agri-Food Canada, \\ London, Ontario, Canada N5V 4T3

\section{C.R. Harris} \\ Department of Environmental Biology, University of Guelph, Guelph, Ontario, \\ Canada N1G 2W1 \\ G. Murphy \\ Ontario Ministry of Agriculture, Food and Rural Affairs, Vineland, Ontario,
} Canada LOR 2E0

\begin{abstract}
Fungus gnats (FG) (Diptera: Sciaridae: Bradysia spp.) are economically important pests of greenhouse flowers. Larvae feed on root tissue and transmit a variety of phytopathogens. Atheta coriaria (Kraatz) (Coleoptera: Staphylinidae) is a new biological control agent (BCA) for FG. To support its successful use by the greenhouse industry, its compatibility with current integrated pest management (IPM) programs used in floriculture was assessed. This included investigations of prey preference, possible detrimental interactions with other soil-dwelling BCAs, and the toxicity to A. coriaria of registered and novel insecticides. Atheta coriaria showed little preference among eggs of different pest species or between pest eggs and eggs of the intraguild predator Hypoaspis aculeifer (Canestrini) (Acari: Mesostigmata: Laelapidae). It preferred FG 1stinstar larvae to larvae and pupae of other soil-dwelling pests. The entomopathogenic nematode Steinernema feltiae (Filipjev) (Rhabditida: Steinernematidae) was compatible with $A$. coriaria, but $H$. aculeifer mites fed on $A$. coriaria larvae. Insect growth regulators with limited contact activity (e.g., diflubenzuron) were compatible with adult $A$. coriaria and had minimal effects on larvae compared with other insecticides. Atheta coriaria can be incorporated into an IPM program for FG if harsh insecticides are avoided, but interactions with predatory mites, as well as its effectiveness against other greenhouse pests when FG are present, require further investigation.
\end{abstract}

\begin{abstract}
Résumé-Les sciarides (FG) (Diptera : Sciaridae : Bradysia spp.) sont des ravageurs d'importance économique des fleurs de serre. Les larves se nourrissent de tissus radiculaires et transmettent une variété de pathogènes. Atheta coriaria (Kraatz) (Coleoptera : Staphylinidae) est un nouvel agent de lutte biologique (BCA) contre les FC. Afin de favoriser l'utilisation efficace de cet agent par l'industrie de la culture en serres, nous évaluons sa compatibilité avec les programmes courants de lutte intégrée (IPM) en vigueur en floriculture. Cette évaluation comprend des études de préférence de proies, d'interactions potentiellement nuisibles avec d'autres BCA vivant dans le sol et de toxicité des insecticides enregistrés et nouveaux pour $A$. coriaria. Atheta coriaria montre peu de préférence pour les oeufs des différentes espèces de ravageurs et ne distingue pas entre les oeufs des ravageurs et ceux du prédateur de même guilde Hypoaspis aculeifer (Canestrini) (Acari : Mesostigmata : Laelapidae). Il préfere les larves de premier stade de FC
\end{abstract}

Received 22 December 2005. Accepted 7 July 2006.

${ }^{1}$ Corresponding author (e-mail: cscottdu@uoguelph.ca). 
aux larves et aux nymphes des autres ravageurs habitant le sol. Le nématode entomopathogène Steinernema feltiae (Filipjev) (Rhabditida : Steinernematidae) est compatible avec A. coriaria, mais les acariens $H$. aculeifer se nourrissent des larves d'A. coriaria. Les régulateurs de croissance d'insectes avec peu d'activité de contact (par ex., le diflubenzuron) sont compatibles avec les adultes d'A. coriaria et ont un effet minimal sur les larves par comparaison aux autres insecticides. Atheta coriaria peut être intégré à un programme IPM pour les FC, si on evite les insecticides durs; il faut cependant étudier plus à fond ses interactions avec les acariens prédateurs, ainsi que son efficacité vis-à-vis des autres ravageurs des serres lorsqu'il y a des FC.

[Traduit par la Rédaction]

\section{Introduction}

Fungus gnats (FG) (Diptera: Sciaridae: Bradysia spp.), Western flower thrips (WFT), Frankliniella occidentalis (Pergande) (Thysanoptera: Thripidae), and shore flies (SF), Scatella stagnalis Fallen (Diptera: Ephydridae), are major pests of greenhouse flowers. FG larvae, ubiquitous in greenhouse crop production, feed on plant roots, reducing root mass and plant size (Harris et al. 1996). More significantly, FG transmit crown and root rot diseases, including those caused by Botrytis, Fusarium, Pythium, Phoma, and (or) Verticillium spp. (Kalb and Miller 1986; Farvin et al. 1988; Gillespie and Menzies 1993; Jarvis et al. 1993). WFT are difficult and expensive to control because of cryptic life stages (Seaton et al. 1997) and their resistance to many insecticides (Broadbent and Pree 1997). WFT injure hosts by feeding and vectoring diseases such as the Tomato spottedwilt virus and Impatiens necrotic spot virus (Moyer and Daub 1994). SF, the least damaging of the three insects, can occur in high numbers in greenhouses and deposit large amounts of frass on foliage, making plants unappealing to consumers. Although they do not directly damage plant material, SF can disseminate Pythium spores (Goldberg and Stanghellini 1990). In the case of each of the above pests, at least one life stage lives in the soil.

Atheta coriaria (Kraatz) (Coleoptera: Staphylinidae) is a biological control agent (BCA) available in Canada primarily for FG control, but it also can be used to control WFT and SF. One adult $A$. coriaria can consume as many as 154 FG eggs, 134 SF eggs, or 95 WFT 2ndinstar larvae in $24 \mathrm{~h}$ (Carney et al. 2002). However, because it has been commercially available only since 2002, its suitability for integrated pest management (IPM) in floriculture production has not been fully assessed.

Determining possible detrimental interactions before releasing a BCA is essential if efficacy and cost-effectiveness of biocontrol are to be achieved. The specific objectives of this study were to $(i)$ determine prey preference of A. coriaria between FG and soil-dwelling stages of SF and WFT, since determining speciesspecific preferences of a predator is important in understanding pest population dynamics (Santos 1991; Clements and Harmsen 1992, 1993); (ii) investigate the possibility of intraguild predation (Rosensheim et al. 1995) between A. coriaria and other soil-dwelling BCAs commonly used for FG control, including the entomopathogenic nematode Steinernema feltiae (Filipjev) (Rhabditida: Steinernematidae) and the predatory mites Stratiolaelaps scimitus (Womersley) (Mesostigmata: Laelapidae) (often mistaken for Hypoaspis miles (Berlese) by biological control producers in North America (Walter and Campbell 2003)) and Hypoaspis aculeifer (Canestrini) (Mesostigmata: Laelapidae); and (iii) assess A. coriaria compatibility with several currently registered and novel insecticides.

\section{Materials and methods}

\section{Prey preference of $A$. coriaria}

\section{Rearing}

Atheta coriaria colonies were started from adult beetles donated by Biobest Canada Ltd. (Leamington, Ontario) and Koppert Canada Ltd. (Scarborough, Ontario). Colonies were reared as described by Carney et al. (2002), using peat moss as the rearing substrate and commercial trout food (Martin Mills Inc., Elmira, Ontario) as food.

FG and SF were collected from a local greenhouse. The latter were identified as $S$. stagnalis by Dr. Matthias Buck of the Insect Systematics Laboratory at the University of Guelph. The FG were identified as Bradysia spp., but as sciarids are a taxonomically difficult group, identification to species was not attempted. However, it is likely that they were Bradysia impatiens Johannsen, as it is the more common 
of the two Nearctic species (the other being Bradysia coprophila (Linter)) associated with greenhouse flowers (Harris et al. 1995). Type specimens have been deposited in the National Insect Collection at Agriculture and Agri-Food Canada (AAFC) in Ottawa.

FG were reared in Plexiglas ${ }^{\circledR}$ cages filled with moistened commercial potting mix (Premier Pro-Mix ${ }^{\circledR}$ 'BX', Premier Tech Ltd., Rivière-du-Loup, Quebec) and fed approximately $1 \mathrm{~g}$ of ground alfalfa meal and two potato slices every $7 \mathrm{~d}$. SF were reared in cages containing hydroponic fibre blocks (Pargro ${ }^{\circledR}$ rock wool, Plant Products Co. Ltd., Brampton, Ontario) covered with a mixture of greenhousecollected algae. The blocks were maintained in approximately $3 \mathrm{~cm}$ of a phosphorus-rich nutrient solution. Colonies were kept in a growth chamber at $20 \pm 1{ }^{\circ} \mathrm{C}, 60 \%-90 \% \mathrm{RH}$, and constant light.

To obtain specific life stages, FG or SF adults were chilled to inactivity by placing them in a freezer at $-4{ }^{\circ} \mathrm{C}$ for $<1 \mathrm{~min}$ and then added to $60 \mathrm{~mm} \times 15 \mathrm{~mm}$ petri dishes containing 3\% Bacto-agar with $1 \%$ streptomycin. Eggs laid on agar were collected with a small camel's-hair paintbrush and either used directly in experiments or placed in clean, $60 \mathrm{~mm} \times$ $15 \mathrm{~mm}$, agar-filled petri dishes to rear to eclosion.

WFT 2nd-instar larvae were obtained from the Greenhouse and Processing Crops Research Centre, AAFC, Harrow, Ontario, and were reared to the pupal stage in $9 \mathrm{~cm}$ ventilated petri dishes containing kidney bean (Phaseolus vulgaris L.; Fabaceae) leaves kept at $25 \pm 1{ }^{\circ} \mathrm{C}$ and $60 \%-90 \% \mathrm{RH}$.

\section{Paired-choice tests}

Tests were conducted in $9 \mathrm{~cm}$ petri dishes containing moistened Whatman No. 3 filter paper for egg assay or filled to a depth of approximately $5 \mathrm{~mm}$ with $3 \%$ Bacto-agar for larval and pupal assays. Atheta coriaria adults were fed Ephestia kuehniella (Keller) (Lepidoptera: Pyralidae) eggs (Beneficial Insectary, Oakrun, California) for 6-8 h prior to experiments, as satiated predators are thought to be more selective in their choice of prey (Bilde and Toft 1994). Prey preference between species was determined by paired-choice tests, using the following combinations: FG eggs vs. SF eggs, FG 1st-instar larvae vs. SF 1st-instar larvae, and FG 1st-instar larvae vs. WFT pupae. For the egg trials, ten $1 \mathrm{~cm}$ diameter circles were indented around the perimeter of the filter paper (Miller and Williams 1983). One FG and one SF egg were placed in each circle, and one adult A. coriaria was added to each dish. For trials between other life stages, 10 larvae or pupae of each species were arranged randomly on the agar. Egg and larval trials were replicated 1318 times. The trial with WFT pupae was replicated 7 times because of limited WFT availability. All petri dishes were sealed with Parafilm ${ }^{\circledR}$ (Pechiney Plastic Manufacturing, Menasha, Wisconsin) and held in the dark at $20 \pm 1{ }^{\circ} \mathrm{C}$ and $90 \% \mathrm{RH}$. Amount of prey consumed was evaluated after $24 \mathrm{~h}$. A paired $t$ test was conducted to determine significant $(\alpha=0.05)$ differences in prey consumption using the PROC UNIVARIATE procedure in SAS v. 8.1 (SAS Institute Inc. 2001).

\section{Intraguild predation}

\section{Compatibility with S. feltiae}

In laboratory bioassays, three concentrations of $S$. feltiae infective juveniles (IJs) were tested on adult $A$. coriaria: $25 \mathrm{IJs} / \mathrm{cm}^{2}, 50 \mathrm{IJs} / \mathrm{cm}^{2}$, and $100 \mathrm{IJs} / \mathrm{cm}^{2}$. Larvae were treated with 12.5 $\mathrm{IJs} / \mathrm{cm}^{2}, 25 \mathrm{IJs} / \mathrm{cm}^{2}$, and $50 \mathrm{IJs} / \mathrm{cm}^{2}$. Nematode concentrations were prepared from commercially available nematodes (Entonem ${ }^{\circledR}$, Koppert Canada Ltd.) using the method described by Glazer and Lewis (2000).

The assay arena for adult $A$. coriaria was a $5 \mathrm{~cm}$ petri dish (10 adults/dish) lined with Whatman No. 1 filter paper and premoistened with $200 \mu \mathrm{L}$ of deionized water. Each nematode treatment (10 replicates/treatment) was transferred to an individual petri dish in $100 \mu \mathrm{L}$ of deionized water using a micropipette. Deionized water ( $100 \mu \mathrm{L} /$ petri dish) was used as a control. To prevent cannibalism, 3rd-instar larvae were tested in 16-well plates (CD International Inc., Pitman, New Jersey) (1 larva/well; 10 wells/plate $=1$ replicate) lined with $1.5 \mathrm{~cm}$ Whatman No. 1 filter paper. Nematode treatments were transferred to each well in $50 \mu \mathrm{L}$ of water, with $50 \mu \mathrm{L} /$ well of deionized water as a control. Only four replicates per treatment were used in the larval experiments because of limited availability of 3rd-instar larvae.

All treatments were kept in the dark at $25 \pm$ $1{ }^{\circ} \mathrm{C}$ and were sealed in plastic bags to prevent desiccation. Mortality was recorded after $48 \mathrm{~h}$. Insect cadavers were then transferred individually to clean $5 \mathrm{~cm}$ petri dishes lined with Whatman No. 1 filter paper that was moistened with 
$500 \mu \mathrm{L}$ of sterilized water to prevent contamination of cadavers with bacterial or fungal pathogens. The cadavers were incubated for 5$7 \mathrm{~d}$ at $25 \pm 1{ }^{\circ} \mathrm{C}$, after which they were dissected and examined for adult nematodes or nematode progeny to confirm that death was caused by $S$. feltiae infection. The experiment was repeated twice. Nematode viability was determined on each treatment date by confirming mobility under a dissecting microscope.

A combined variance analysis for each experiment was conducted, since there was no significant interaction between treatments and trial dates (Bowley 1999). Significant differences were detected using Tukey's multiple means comparison.

In growth room tests, $10 \mathrm{~cm}$ diameter plastic plant pots (10 replicates/treatment) were filled with $40 \mathrm{~g}$ of dry commercial potting mix (Premier Pro-Mix ${ }^{\circledR}$ 'BX') moistened with $100 \mathrm{~mL}$ of deionized water. Concentrations of $25 \mathrm{IJs} / \mathrm{cm}^{2}$, $50 \mathrm{IJs} / \mathrm{cm}^{2}$ (recommended rate - Koppert Canada Ltd.), and $100 \mathrm{IJs} / \mathrm{cm}^{2}$ were delivered in $5 \mathrm{~mL}$ of deionized water to individual pots. Nematode treatments were watered in with $55 \mathrm{~mL}$ of deionized water, and approximately 20-30 min later, twenty 3 rd-instar larvae were added to each pot along with excess E. kuehniella eggs. Deionized water $(60 \mathrm{~mL})$ was used as a control. Each pot had a cylindrical Plexiglas cage, with holes covered with fine screening for ventilation, fitted tightly on top to prevent escapes. The bottom of each pot was also screened to prevent beetle escapes through the drainage holes. Treatments were randomized in a growth room that simulated greenhouse conditions $\left(24 \pm 1{ }^{\circ} \mathrm{C}, 65 \%-95 \% \mathrm{RH}\right.$, 16L:8D photoperiod). As dead larvae were extremely difficult to locate in the soil, pots were incubated for $12 \mathrm{~d}$ to determine adult $A$. coriaria emergence. For data analysis, percent emergence was converted to percent mortality using the following formula (Powell and Webster 2004):

$$
\begin{aligned}
& {[1-(\text { no. of beetles surviving / }} \\
& \text { no. of beetles at start })] \times 100
\end{aligned}
$$

Data were corrected for nonemergence $(=20 \%)$ in the controls using Abbott's formula (Abbott 1925). An ANOVA with Tukey's multiple means comparison was used to determine significant ( $\alpha=0.05$ ) differences between treatments.

\section{Compatibility with predatory mites in no- choice bioassays}

In tests using $A$. coriaria as prey, we used a bioassay method modified from Wright and Chambers (1994). The assay arena consisted of a $20 \mathrm{~mL}$ snap-top vial filled to approximately $1 \mathrm{~cm}$ below the rim with a mixture of plaster of Paris (Burma Latex Co., Toronto, Ontario) and activated charcoal (Sigma-Aldrich Co., St. Louis, Missouri) (7:1) to maintain RH. A small amount of ground trout food was added as a food source for the A. coriaria larvae. Ten 1 st instars, seven 2nd instars, or five 3rd instars of A. coriaria larvae were placed in individual vials. Ten to fifteen replicates per $A$. coriaria life stage were used, depending on larval availability. Atheta coriaria eggs were not tested because of insufficient numbers. One starved (i.e., for $6 \mathrm{~h}$ prior to the experiment) female $S$. scimitus (Koppert Canada Ltd.) was placed in each vial with the $A$. coriaria larvae. As $A$. coriaria larvae can be cannibalistic, vials containing larvae of each stage at the same densities as above, but without a mite, were used as controls (five replicates per stage). Vials were sealed in plastic bags to prevent desiccation and placed in an incubator at $20 \pm 1{ }^{\circ} \mathrm{C}$. After $24 \mathrm{~h}$, the number of $A$. coriaria larvae consumed by $S$. scimitus was counted. Mean number of $A$. coriaria larvae of each instar cannibalized in the controls was used as a correction factor. Mean corrected number of prey consumed and standard errors were determined. The trial was repeated with $H$. aculeifer, with 9-15 replicates per $A$. coriaria stage.

The same methods just described were used to observe $H$. aculeifer as prey. One starved adult $A$. coriaria was added to a vial containing twenty $H$. aculeifer eggs, fifteen 3- to 6-day-old nymphs, fifteen 7- to 10-day-old nymphs, or ten adult mites. Hypoaspis aculeifer eggs were obtained by placing one female on a sweet pepper (Capsicum sp.; Solanaceae) leaf placed on agar in a petri dish with frozen $E$. kuehniella eggs as food, kept at $24 \pm 1{ }^{\circ} \mathrm{C}$ and approximately $50 \%$ RH. Nymphs of specific ages were obtained by collecting $H$. aculeifer eggs over a $3 \mathrm{~d}$ period and incubating them at $21 \pm 1{ }^{\circ} \mathrm{C}$ and approximately $50 \% \mathrm{RH}$ until they hatched and reached the desired age. Nine to twelve replications per $H$. aculeifer stage were used. 
Prey preference of A. coriaria between pest and intraguild prey

Methods and statistics used are the same as those described earlier. Paired-choice combinations were (i) FG eggs vs. $H$. aculeifer eggs and (ii) SF eggs vs. H. aculeifer eggs.

\section{Insecticide compatibility}

\section{Insecticides}

Technical-grade insecticides ( $>95 \%$ pure) available for use in direct-contact bioassays included the insect growth regulators cyromazine, diflubenzuron, and novaluron, the chloronicotinyl imidacloprid, and the carbamate bendiocarb. Formulated insecticides used in growth room bioassays and suitable as soil drenches were Citation 75WP ${ }^{\circledR}$ (cyromazine; Syngenta Crop Protection Canada, Guelph, Ontario), Dimilin 25WP (diflubenzuron; Crompton $\mathrm{Co} / \mathrm{Cie}$, Middlebury, Connecticut), Intercept 60WP ${ }^{\otimes}$ (imidacloprid; Bayer CropScience, Calgary, Alberta), and Trumpet $80 \mathrm{WP}^{\circledR}$ (bendiocarb; Bayer CropScience).

\section{Direct-contact bioassays}

Direct-contact assays were carried out using a Potter spray tower (Potter 1952) located at the Southern Crop Protection and Food Research Centre, AAFC, London, Ontario. Insecticides were dissolved in acetone-olive oil (19:1) for use against adult $A$. coriaria. Acetone alone was used as the solvent for the larval bioassay, as the acetone-olive oil mixture resulted in high mortality of control larvae. The solvent was used as the control in each assay. Treatments were applied to adult and 3rd-instar A. coriaria as described by Harris et al. (1962). Adults were first chilled by placing them in a $-20^{\circ} \mathrm{C}$ freezer for approximately $90 \mathrm{~s}$. Each insecticide was tested at four concentrations: $0.0001 \%$, $0.001 \%, 0.01 \%$, and $0.1 \%(w / v)$ active ingredient. Four repetitions of 10 insects were tested at each concentration.

Following treatment, adults were placed in $5 \mathrm{~cm}$ petri dishes containing Whatman No. 1 filter paper moistened with $500 \mu \mathrm{L}$ of water. Fresh food was given after $48 \mathrm{~h}$, and $20 \mu \mathrm{L}$ of water was added every $24 \mathrm{~h}$. Larvae were placed individually in $2 \mathrm{~cm}$ diameter wells of bioassay trays with ventilated lids to prevent cannibalism. Each well was filled to within $0.5 \mathrm{~cm}$ from the top with a mixture of plaster of Paris and charcoal (see Intraguild predation). Trays were sealed in plastic bags to prevent desiccation. Larvae were given an excess of frozen $E$. kuehniella eggs at $0 \mathrm{~h}$ but were not fed again, as all larvae had begun to pupate by $48 \mathrm{~h}$.

Containers were randomized and held at $24 \pm$ $1{ }^{\circ} \mathrm{C}$ and $50 \% \mathrm{RH}$. Mortality was assessed at $24,48,72$, and $96 \mathrm{~h}$. Data were corrected for natural mortality ( $<8 \%$ in the adult bioassay on all days; $\leq 20 \%$ in the 3rd-instar larval bioassay on all days) using Abbott's formula (Abbott 1925).

\section{Growth room bioassays}

Adult trial. Growth room bioassays were done as described for $S$. feltiae (see Intraguild predation). For insecticides applied as soil drenches (cyromazine, diflubenzuron, and imidacloprid), pots were treated with $80 \mathrm{~mL}$ of insecticide mixture at the recommended Canadian label rates $(133 \mathrm{~g} / 1000 \mathrm{~L}, 150 \mathrm{~g} / 1000 \mathrm{~L}$, and $133 \mathrm{~g} / 1000 \mathrm{~L}$ of water, respectively). To simulate a soil-surface spray of bendiocarb (as per Canadian label directions), $5 \mathrm{~mL}$ of product at the recommended label rate $(125 \mathrm{~g} / 100 \mathrm{~L}$ of water) was distributed evenly over the soil surface. Water $(75 \mathrm{~mL})$ was added to each pot prior to addition of the bendiocarb to keep the amount of water in each of the treatments consistent. Deionized water $(80 \mathrm{~mL})$ was added to each of five control pots. Twenty adult $A$. coriaria were added to each pot with excess trout food (approximately $1 \mathrm{~g}$ ). Each pot was caged and screened as described in Intraguild predation. Treatments were held at $25 \pm 1{ }^{\circ} \mathrm{C}, 65 \%-$ 95\% RH, and 16L:8D photoperiod. The percentage of adult beetles surviving was determined after $96 \mathrm{~h}$ and converted to percent mortality (see Intraguild predation). Data were corrected for natural mortality $(<5 \%)$ using Abbott's formula (Abbott 1925).

Larval trial. The method described above was used except twenty 3rd-instar or twenty 2nd-instar larvae were added to $10 \mathrm{~cm}$ diameter pots. Larvae were fed an excess of frozen E. kuehniella eggs every $48 \mathrm{~h}$. Pots were incubated at $26 \pm 1{ }^{\circ} \mathrm{C}$ and $65 \%-95 \% \mathrm{RH}$. After $12 \mathrm{~d}$, the pots containing $3 \mathrm{rd}$ instars were sieved to determine percent adult emergence. Pots containing 2nd instars were sieved after $14 \mathrm{~d}$. Emergence was converted to corrected natural mortality using Abbott's formula (Abbott 1925), with $31 \%$ non-emergence observed in the 3rd-instar controls and $26 \%$ non-emergence observed in the 2 nd-instar controls. 
Table 1. Mean number ( \pm SE) of fungus gnats (FG) (Bradysia spp.), shore flies (SF) (Scatella stagnalis), and western flower thrips (WFT) (Frankliniella occidentalis) eaten by one satiated adult Atheta coriaria after $24 \mathrm{~h}$ in a paired-choice bioassay.

\begin{tabular}{|c|c|c|c|c|}
\hline \multicolumn{2}{|c|}{ Prey species choice } & \multicolumn{2}{|c|}{ Mean no. eaten } & \multirow{2}{*}{$\begin{array}{c}\text { Statistics* } \\
P, n\end{array}$} \\
\hline Prey 1 & Prey 2 & Prey 1 & Prey 2 & \\
\hline FG eggs & SF eggs & $2.62 \pm 0.61$ & $1.69 \pm 0.61$ & $0.208,13$ \\
\hline FG 1st instars & SF 1st instars & $4.22 \pm 0.49$ & $2.00 \pm 0.49$ & $<0.001,18$ \\
\hline FG 1st instars & WFT pupae & $4.57 \pm 0.61$ & $2.57 \pm 0.61$ & $0.0064,7$ \\
\hline
\end{tabular}

*Significant difference $(\alpha=0.05)$ determined using paired $t$ tests.

For all insecticide trials, an ANOVA was conducted using the PROC GLM procedure in SAS v. 8.1 (SAS Institute Inc. 2001). Significant differences among treatments were determined with Tukey's multiple means comparison. Data from the direct-contact toxicity experiments were transformed using an arcsine square-root transformation prior to analysis to better meet the assumptions of variance (Bowley 1999). Insecticides were classified as nontoxic ( $<25 \%$ mortality), slightly toxic (25\%-50\% mortality), moderately toxic $(50 \%-75 \%$ mortality), or toxic ( $>75 \%$ mortality) based on the International Organization for Biological Control classification for insecticide toxicity (Pietrantonio and Benedict 1999).

\section{Results}

\section{Prey preference of $\boldsymbol{A}$. coriaria}

There was no significant difference between the number of FG eggs and the number of SF eggs eaten by $A$. coriaria. However, significantly more $(P<0.05)$ FG 1 st-instar larvae were eaten compared with either SF larvae or WFT pupae (Table 1).

\section{Intraguild predation}

\section{Compatibility with S. feltiae}

In laboratory bioassays with adult $A$. coriaria, there were no significant differences among any of the nematode treatments and the control (Fig. 1A), nor was evidence of nematode infection found in any of the adult cadavers. In the larval trials, mortality in all nematode treatments was higher than that in the control. The highest mortality $(26.9 \%)$, seen in the $50 \mathrm{IJs} / \mathrm{cm}^{2}$ treatment (Fig. 1B), was significantly different from the control. However, only $40 \%, 39 \%$, and $60 \%$ of the mortality of 3rd instars in the $12.5 \mathrm{IJs} / \mathrm{cm}^{2}, 25 \mathrm{IJs} / \mathrm{cm}^{2}$, and 50
$\mathrm{IJs} / \mathrm{cm}^{2}$ treatments, respectively, was confirmed to be due to nematode infection upon dissection (Fig. 1B). IJs and a limited number of pre-adult (4th instars) and adult nematodes (both males and females) were found.

In the growth room bioassays, when nematode treatments were corrected for nonemergence observed in the controls, twice the rate recommended by Koppert Canada Ltd. $\left(100 \mathrm{IJs} / \mathrm{cm}^{2}\right)$ caused significantly more mortality $(25.4 \%)$ of 3 rd-instar $A$. coriaria than the lowest rate (25 $\left.\mathrm{IJs} / \mathrm{cm}^{2} ; 12.8 \%\right)$ (Fig. 2).

\section{Compatibility with predatory mites in no- choice bioassays}

Stratiolaelaps scimitus and $H$. aculeifer attacked all larval stages of $A$. coriaria but consumed more 1st than 2nd or 3rd instars (Table 2). Atheta coriaria adults consumed all $20 \mathrm{H}$. aculeifer eggs provided in each replicate and almost all of the 2- to 5-day-old nymphs. Fewer 7- to 10-day-old nymphs and a negligible number of adults were consumed.

\section{Prey preference of A. coriaria between pest and intraguild prey}

The number of $H$. aculeifer eggs eaten by A. coriaria did not significantly differ from the number of FG eggs eaten but was significantly higher than the number of SF eggs eaten $(P=$ 0.015) (Table 3).

\section{Insecticide compatibility}

\section{Direct contact bioassays}

All three insect growth regulators (IGRs) were considered nontoxic to adult $A$. coriaria after $96 \mathrm{~h}$ (Fig. 3A) and were significantly less toxic than $0.01 \%$ and $0.1 \%$ bendiocarb and $0.001 \%, 0.01 \%$, and $0.1 \%$ imidacloprid. The two highest concentrations of bendiocarb and imidacloprid $(0.01 \%$ and $0.1 \%)$ were toxic to adult $A$. coriaria. 
Fig. 1. Average corrected percent mortality, with standard errors, of (A) adult and (B) 3rd-instar Atheta coriaria $48 \mathrm{~h}$ after exposure to Steinernema feltiae infective juveniles (IJs). Average percentage of total mortality due to confirmed nematode infection is shown in Fig. 1B. Columns with different letters (total mortality) or symbols (total confirmed infections) are significantly different (Tukey's, $\alpha=0.05$ ).
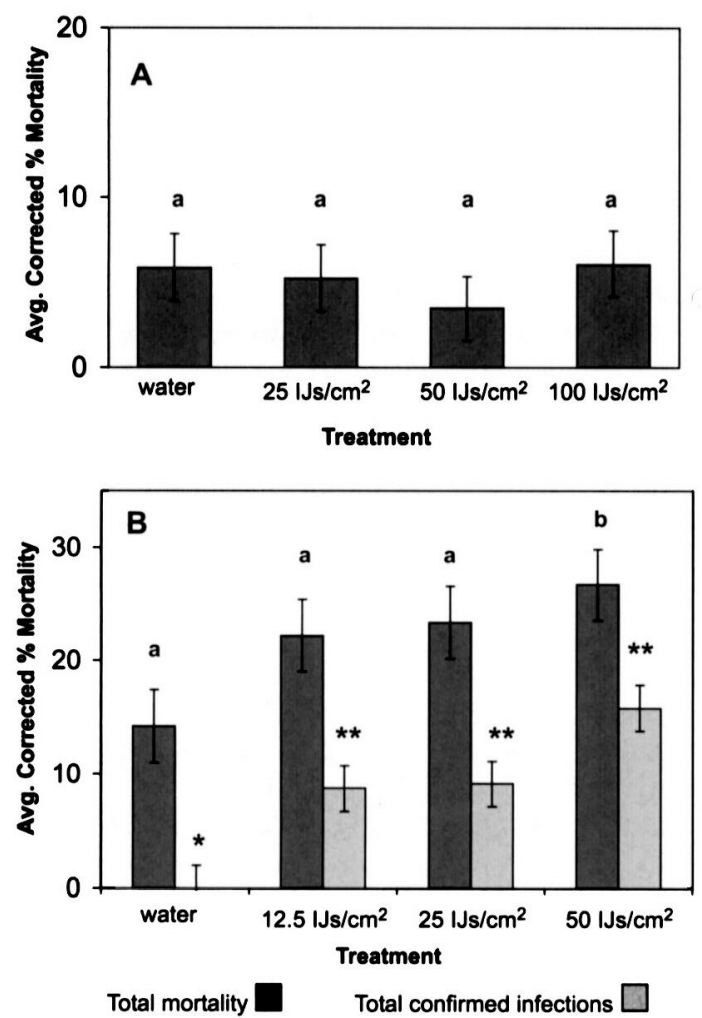

The mortality caused by the IGRs to 3rdinstar $A$. coriaria was not significantly different from that caused by imidacloprid and bendiocarb at concentrations of $0.0001 \%$ to $0.01 \%$ after $96 \mathrm{~h}$ (Fig. 3B). At $0.1 \%$, novaluron and diflubenzuron were not significantly different from imidacloprid or bendiocarb (Fig. 3B); all were considered toxic, causing $>75 \%$ mortality. Cyromazine was not significantly different from novaluron or diflubenzuron at this concentration but was significantly less toxic than imidacloprid and bendiocarb and was considered moderately toxic.

\section{Growth room bioassays}

Cyromazine and diflubenzuron caused significantly less mortality of adult $A$. coriaria than bendiocarb or imidacloprid (Fig. 4A), which
Fig. 2. Average corrected percent mortality, with standard errors, of 3rd-instar Atheta coriaria (corrected for non-emergence of adult $A$. coriaria in control treatments) when exposed to one-half ( 25 infective juveniles $\left.(\mathrm{IJs}) / \mathrm{cm}^{2}\right)$, one $\left(50 \mathrm{IJs} / \mathrm{cm}^{2}\right)$, and two $\left(100 \mathrm{IJs} / \mathrm{cm}^{2}\right)$ times the recommended rate of Steinernema feltiae. Columns with different letters are significantly different (Tukey's, $\alpha=0.05$ ).

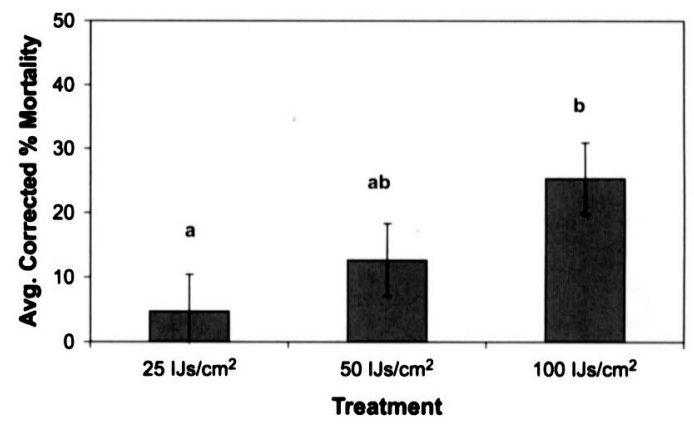

caused $>90 \%$ mortality. In the emergence tests with both 2 nd- and 3rd-instar A. coriaria, diflubenzuron was nontoxic and significantly different from the other treatments (Figs. 4B and $4 \mathrm{C}$ ). Cyromazine resulted in $65 \%$ mortality to the 3rd instars, making it moderately toxic, but was still significantly less toxic than bendiocarb or imidacloprid (Fig. 4B). With 2nd instars, however, cyromazine caused $82 \%$ mortality (Fig. 4C) and was not significantly different from the other insecticides.

\section{Discussion}

Miller and Williams (1983) conducted prey preference trials with $A$. coriaria using eight species of nitidulid beetles and the house fly, Musca domestica L. (Diptera: Muscidae). Although preferences existed, they hypothesized that the wide range of hosts that $A$. coriaria fed on suggested that this biological control agent could easily switch from a preferred prey species to a nonpreferred species as prey populations fluctuated. In our experiments, $A$. coriaria consumed a substantial number of SF and WFT even though these were not the preferred prey. Therefore, A. coriaria could help control these pests when FG larvae are at low density.

The absence of significant preference between FG and SF eggs and even FG and $H$. aculeifer is in agreement with the generalist and opportunistic behaviour of $A$. coriaria (Carney et al. 2002). Atheta coriaria's potential consumption of Hypoaspis spp. eggs could exceed the 20 eggs presented in this trial, as Carney et al. 


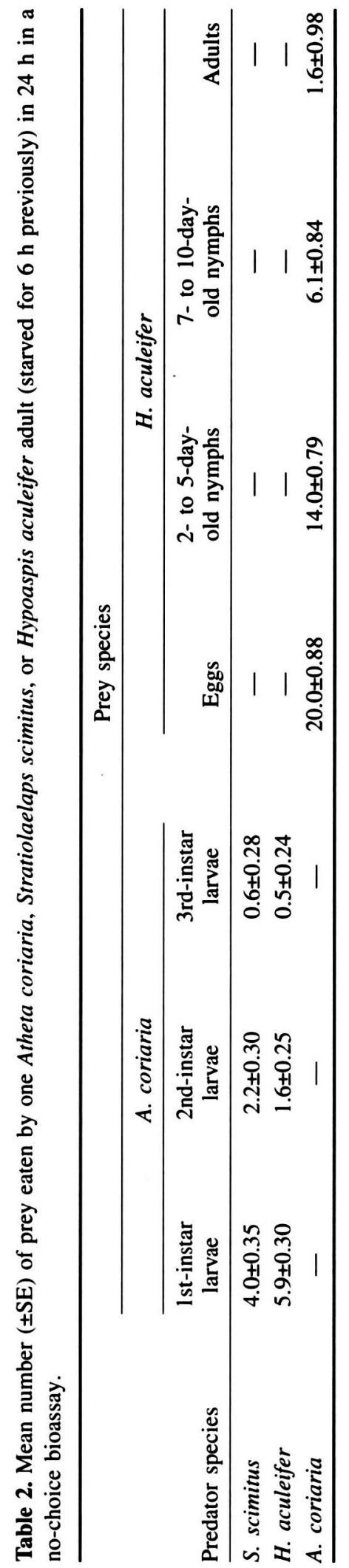

(2002) showed that this predator can eat $>150$ B. impatiens eggs in $24 \mathrm{~h}$.

The number of 1 st-instar $A$. coriaria eaten by predatory mites in this experiment also is a concern. Stratiolaelaps scimitus is known to consume a similar number (approximately 4.0 ) of FG 2nd instars in $24 \mathrm{~h}$ (Wright and Chambers 1994). Stratiolaelaps scimitus is reported to consume only moving prey (Wright and Chambers 1994), but $H$. aculeifer readily eats eggs (Ragusa and Zedan 1988), which may exacerbate any potential impacts on Atheta populations.

This bidirectional intraguild predation (IGP) could negatively affect FG control. Previous greenhouse studies, however, have illustrated that a significant bidirectional IGP at the individual level may not be significant at the population level (Venzon et al. 2001).

The entomopathogenic nematode $S$. feltiae penetrated $A$. coriaria larvae, but low total mortality $(<30 \%)$ in laboratory and growth room assays, and the even lower number of confirmed infections in the laboratory assay, showed that A. coriaria is a poor host. It appears that $S$. feltiae cannot reproduce in $A$. coriaria, as no progeny were seen in the 3rd-instar cadavers after $7 \mathrm{~d}$. Atheta coriaria populations should not be significantly affected by $S$. feltiae applications in the greenhouse, especially since known preferred hosts (e.g., dipteran larvae) will be present in the media.

These trials also have illustrated the benefits of reduced-risk insecticides in IPM. Although toxic to larvae at high concentrations by direct contact, diflubenzuron was nontoxic (i.e., $<25 \%$ mortality) to 2 nd- and 3 rd-instar A. coriaria when applied as formulated product. These results are similar to those reported by Gordon and Cornect (1986), who found no effect of formulated diflubenzuron on 1st-instar Aleochara bilineata Gyllenhal larvae (Staphylinidae: Aleocharinae). Diflubenzuron acts primarily as a stomach poison, resulting in limited toxicity to beneficials (Tomlin 2003). Its capacity to bind rapidly to soil particles and organic matter and to degrade quickly ( $\mathrm{LT}_{50}<7 \mathrm{~d}$ ) (Tomlin 2003) likely explains the differences seen in the directcontact toxicity trials versus the growth room bioassays.

IPM programs must be efficacious, environmentally sound, and cost-effective. In Canada, the cost of a single application of either $A$. coriaria or an insecticide for FG control is comparable. However, some insecticides require repeated 
Table 3. Mean number ( \pm SE) of fungus gnat (FG) (Bradysia spp.), shore fly (SF) (Scatella stagnalis), or Hypoaspis aculeifer eggs eaten by one adult (satiated) Atheta coriaria in $24 \mathrm{~h}$ in a paired-choice bioassay.

\begin{tabular}{|c|c|c|c|c|}
\hline \multicolumn{2}{|c|}{ Prey species } & \multicolumn{2}{|c|}{ Mean no. of prey eaten } & \multirow{2}{*}{$\begin{array}{c}\text { Statistics* } \\
P, \mathrm{n}\end{array}$} \\
\hline Prey 1 & Prey 2 & Prey 1 & Prey 2 & \\
\hline FG eggs & H. aculeifer eggs & $5.1 \pm 0.77$ & $4.8 \pm 0.77$ & $0.720,17$ \\
\hline SF eggs & H. aculeifer eggs & $1.7 \pm 0.72$ & $3.1 \pm 0.72$ & $0.015,15$ \\
\hline
\end{tabular}

*Significant difference ( $\alpha=0.05$ ) determined using paired $t$ tests.

Fig. 3. Average corrected percent mortality of (A) adult $\left(R^{2}=0.900\right)$ and (B) 3rd-instar $\left(R^{2}=0.808\right)$ Atheta coriaria $96 \mathrm{~h}$ after exposure to technicalgrade insecticides applied with a Potter spray tower (untransformed data shown). Columns with different letters are significantly different (Tukey's, $\alpha=0.05$ ).
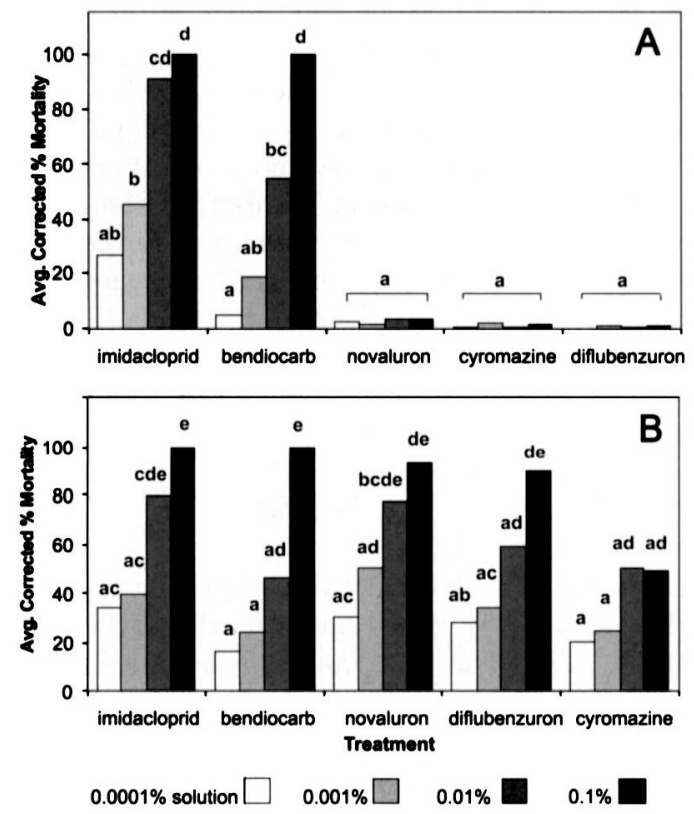

applications, can be phytotoxic, and can restrict reentry to the greenhouse. Currently, $A$. coriaria is slightly more expensive than the predatory mites tested or $S$. feltiae. However, it has been commercially available only since the fall of 2002 , and cost may decrease as its use becomes more widespread and increased production leads to economies of scale.

Our data also suggest that $A$. coriaria may help to suppress WFT and SF. Steinernema feltiae control FG and have little impact on phorids (Jess and Bingham 2004). The predatory mites examined here target smaller FG larvae and bulb mites (Rhizoglyphus robini (Claparède)) (Astigmata: Acaridae) and have
Fig. 4. Average corrected percent mortality, with standard errors, of (A) adult $\left(R^{2}=0.973\right)$, (B) 3rdinstar $\left(R^{2}=0.908\right)$, and (C) 2nd-instar $\left(R^{2}=0.968\right)$ Atheta coriaria following exposure to formulated insecticides applied to commercial potting mix in $10 \mathrm{~cm}$ plant pots at the recommended label rates. Columns with different letters are significantly different (Tukey's, $\alpha=0.05$ ).
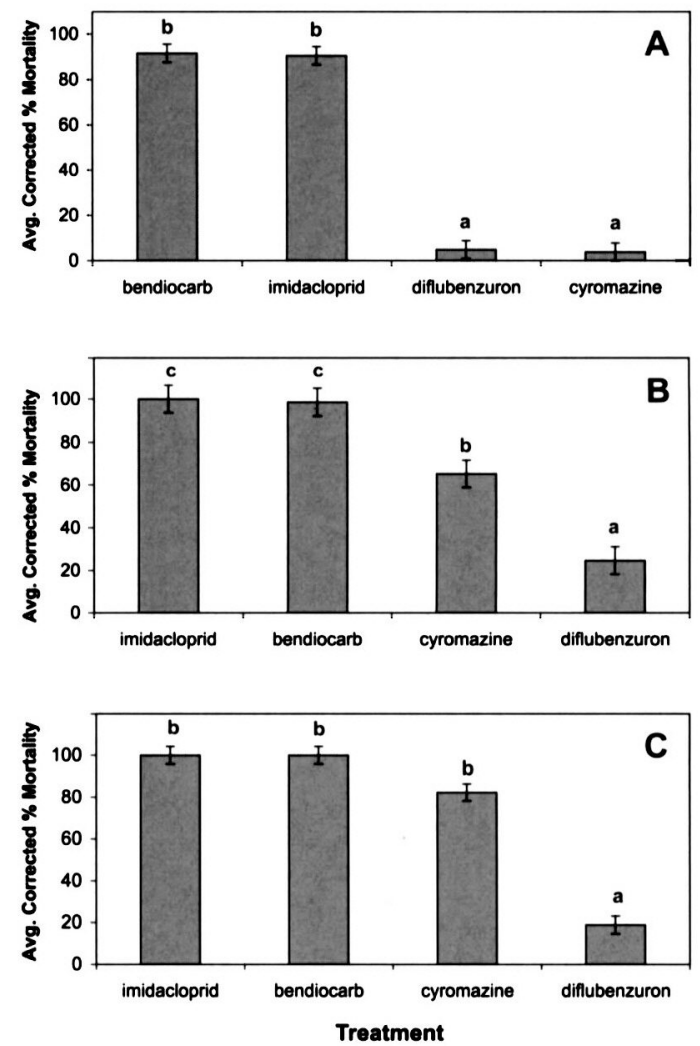

little impact on WFT pupae, collembola, phorids, and eggs of the pest moth Duponchelia fovealis (Zeller) (Jess and Bingham 2004; Biobest Biological Systems 2005; Koppert Biological Systems 2005). Atheta coriaria may prove to be the most cost-effective choice given its broad spectrum of activity. 
Atheta coriaria could be incorporated effectively into a greenhouse floriculture IPM program for FG control. In a prophylactic approach, $S$. feltiae and $A$. coriaria could be applied together soon after potting, with a second combined application a few weeks later. However, if FG populations are abundant, slower-acting biological controls would not prevent economic damage and insecticides would be required. Currently, diflubenzuron would be the most appropriate insecticide to incorporate in the program because of its compatibility with A. coriaria, which could be safely introduced approximately 4-7 d after insecticide application to provide long-term FG control.

Our research has shown that $A$. coriaria has potential in an IPM program for FG; however, the data have also demonstrated that in dealing with a multiple pest/predator complex, a single pest management problem cannot be considered in isolation. In the case of $A$. coriaria, further research under commercial greenhouse conditions is needed to determine $(i)$ effectiveness of A. coriaria for FG control when used alone or in combination with $S$. feltiae, (ii) potential to control SF and WFT in the presence of the preferred host, and (iii) interactions with beneficial predatory mites. Such studies are necessary to clarify the role of $A$. coriaria in a comprehensive IPM program for greenhouse floriculture.

\section{Acknowledgements}

Thanks are extended to J. McNeil at AAFC (London) and B. Beattie and L. Conroy at the University of Guelph for their technical assistance. Thanks also go to E. Lindquist from the Invertebrate Systematics - Acarology Unit, AAFC, Ottawa, Ontario, for confirming the indentification of $S$. scimitus. Funding for this research was provided by Flowers Canada Ontario, a Natural Sciences and Engineering Research Council of Canada - Industrial Postgraduate Scholarship (to S.J.), and the University of Guelph - Ontario Ministry of Agriculture, Food and Rural Affairs Plants Program. We also thank Bayer CropSciences Inc., Biobest Canada Ltd., Crompton Co./Cie., Koppert Biological Systems, and Syngenta Crop Protection Inc. for their generous donations of materials.

\section{References}

Abbott, W.S. 1925. A method for computing the effectiveness of an insecticide. Journal of Economic Entomology, 18: 265-267.

Bilde, T., and Toft, S. 1994. Prey preference and egg production of the carabid beetle Agonum dorsale. Entomologia Experimentalis et Applicata, 73: 151-156.

Biobest Biological Systems. 2005. Products. Biological control: beneficial insects and mites. Available from http://www.biobest.be/ [accessed March 2005].

Bowley, S.R. 1999. A hitchhiker's guide to statistics in plant biology. Plants et al. Inc., Guelph, Ontario.

Broadbent, A.B., and Pree, D.J. 1997. Resistance to insecticides in populations of Frankliniella occidentalis (Pergande) (Thysanoptera: Thripidae) from greenhouses in the Niagara region of Ontario. The Canadian Entomologist, 129: 907-913.

Carney, V.A., Diamond, J.C., Murphy, G.D., and Marshall, D. 2002. The potential of Atheta coriaria Kraatz (Coleoptera: Staphylinidae) as a biological control agent for use in greenhouse crops. IOBC/wprs Bulletin, 25(1): 37-40.

Clements, D.R., and Harmsen, R. 1992. Stigmaeidphytoseiid interactions and the impact of natural enemy complexes on plant-inhabiting mites. Experimental and Applied Acarology, 14: 327-341.

Clements, D.R., and Harmsen, R. 1993. Prey preferences of adult and immature Zetzellia mali Ewing (Acari: Stigmaeidae) and Typhlodromus caudiglans Schuster (Acari: Phytoseiidae). The Canadian Entomologist, 125: 967-969.

Farvin, R.J., Rahe, J.E., and Mauza, B. 1988. Pythium spp. associated with crown rot of cucumbers in British Columbia greenhouses. Plant Disease, 72: 683-687.

Gillespie, D.R., and Menzies, J.G. 1993. Fungus gnats vector Fusarium oxysporum f.sp. radicis lycopersici. Annals of Applied Biology, 123: 539-544.

Glazer, I., and Lewis, E.E. 2000. Bioassays for entomopathogenic nematodes. In Bioassays of entomopathogenic microbes and nematodes. Edited by A. Navon and K.R.S. Ascher. CABI Publishing, Wallingford, United Kingdom. pp. 229-247.

Goldberg, N.P., and Stanghellini, M.E. 1990. Ingestion-egestion and aerial transmission of Pythium aphanidermatum by shore flies (Ephydrinae: Scatella stagnalis). Phytopathology, 80: 1244-1246.

Gordon, R., and Cornect, M. 1986. Toxicity of the insect growth regulator diflubenzuron to the rove beetle Aleochara bilineata, a parasitoid and predator of the cabbage maggot, Delia radicum. Entomologia Experimentalis et Applicata, 42: 179-185.

Harris, C.R., Manson, G.F., and Mazurek, J.H. 1962. Development of insecticidal resistance by soil insects in Canada. Journal of Economic Entomology, 55: 777-780. 
Harris, M.A., Oetting, R.D., and Gardner, W.A. 1995. Use of entomopathogenic nematodes and a new monitoring technique for control of fungus gnats, Bradysia coprophila (Diptera: Sciaridae), in floriculture. Biological Control, 5: 412-418.

Harris, M.A., Gardner, W.A., and Oetting, R.D. 1996. A review of the scientific literature on fungus gnats (Diptera: Sciaridae) in the genus Bradysia. Journal of Entomological Science, 31: 252-276.

Jarvis, W.R., Shipp, J.L., and Gardiner, R.B. 1993. Transmission of Pythium aphanidermatum to greenhouse cucumber by the fungus gnat Bradysia impatiens (Diptera: Sciaridae). Annals of Applied Biology, 122: 23-29.

Jess, S., and Bingham, J.F.W. 2004. Biological control of sciarid and phorid pests of mushroom with predatory mites from the genus Hypoaspis (Acari: Hypoaspidae) and the entomopathogenic nematode Steinernema feltiae. Bulletin of Entomological Research, 94: 159-167.

Kalb, D.W., and Miller, R.L. 1986. Dispersal of Verticillium albo-atrum by the fungus gnat (Bradysia impatiens). Plant Disease, 70: 752-753.

Koppert Biological Systems. 2005. Pest control. Available from http://www.koppert.nl.cgi-bin/ x0210.pl?lang=e\&kpgr_srcID=5 [accessed March 2005].

Miller, K.V., and Williams, R.N. 1983. Biology and host preference of Atheta coriaria (Coleoptera: Staphylinidae), an egg predator of Nitidulidae and Muscidae. Annals of the Entomological Society of America, 76: 159-161.

Moyer, J.W., and Daub, M.E. 1994. Tomtato spotted wilt virus/Impatiens necrotic spot virus: where we've been and where we're going. In Proceedings for the Tenth Conference on Insects and Disease Management on Ornamentals, 19-21 February 1994. Society of American Florists, Dallas, Texas. pp. 86-93.

Pietrantonio, P.V., and Benedict, J.H. 1999. Effect of new cotton insecticide chemistries, tebufenozide, spinosad and chlorfenapyr on Orius insidiosus and two Cotesia species. Southwestern Entomologist, 24: 21-29.

Potter, C. 1952. An improved laboratory apparatus for applying direct sprays and surface films, with data on the electrostatic charge on atomized spray fluids. Annals of Applied Biology, 39: 1-28.

Powell, J.R., and Webster, J.M. 2004. Interguild anatagonism between biological controls: impact of entomopathogenic nematode application on an aphid predator, Aphidoletes aphidimyza (Diptera: Cecidomyiidae). Biological Control, 30: 110-118.

Ragusa, S., and Zedan, M.A. 1988. Biology and predation of Hypoaspis aculeifer (Canestrini) (Parasitiformes, Dermanyssidae) on Rhizoglyphus echinopus (Fum. \& Rob) (Acariformes, Acaridae). Redia, 71: 213-225.

Rosensheim, J.A., Kaya, H.K., Ehler, L.E., Marois, J.J., and Jaffee, B.A. 1995. Intraguild predation among biological-control agents: theory and evidence. Biological Control, 5: 303-335.

Santos, M.A. 1991. Searching behavior and associational response of Zetzellia mali (Acarina: Stigmaeidae). Experimental and Applied Acarology, 11: 81-87.

SAS Institute Inc. 2001. SAS/STAT ${ }^{*}$. Version 8.1 [computer program]. SAS Institute Inc., Cary, North Carolina.

Seaton, K.A., Cook, D.F., and Hardie, D.C. 1997. The effectiveness of a range of insecticides against western flower thrips (Frankliniella occidentalis) (Thysanoptera: Thripidae) on cut flowers. Australian Journal of Agricultural Research, 48: 781-7787.

Tomlin, C.D.S. (Editor). 2003. The pesticide manual. 13th ed. British Crop Protection Council, Hampshire, United Kingdom.

Venzon, M., Janssen, A., and Sabelis, M.W. 2001. Prey preference, intraguild predation and population dynamics of an arthropod food web on plants. Experimental and Applied Acarology, 25: 785808.

Walter, D.E., and Campbell, N.J.H. 2003. Exotic vs. endemic biocontrol agents: would the real Stratiolaelaps miles (Berlese) (Acari: Mesostigmata: Laelapidae) please stand up? Biological Control, 26: 253-269.

Wright, E.M., and Chambers, R.J. 1994. The biology of the predatory mite Hypoaspis miles (Acari: Laelapidae), a potential biological control agent of Bradysia paupera (Dipt.: Sciaridae). Entomophaga, 39: 225-235. 